\title{
Molecular Characterization of Dendrobium Orchid Species from Western Ghat Region of Karnataka using RAPD and SSR Markers
}

\author{
B. Basavaraj ${ }^{1}$, N. Nagesha ${ }^{1 *}$ and M. Jadeyegowda ${ }^{2}$ \\ ${ }^{1}$ Department of Plant Biotechnology, College of Agriculture, University of Agricultural \\ Sciences, GKVK, Bengaluru-560065, Karnataka, India \\ ${ }^{2}$ Department of Natural Resource Management, College of Forestry, Ponnampet-571216 \\ Karnataka, India \\ *Corresponding author
}

\section{Keywords}

Dendrobium,

Morphological characters, Genetic diversity, RAPD marker, SSR marker

\section{Article Info}

Accepted:

15 December 2019 Available Online: 20 January 2020

\section{A B S T R A C T}

Orchids are the most beautiful flowering, highly evolved ornamental plants and also have medicinal importance. In the present study, genetic diversity among six Dendrobium species was analysed using morphological characters and molecular markers including RAPD and SSR markers. Morphological characters analysed were leaf shoot and flower characters of six Dendrobium species. The variability in morphology was found among the species. Further, the genetic diversity among the species was determined by using RAPD and SSR markers. Out of 52 RAPD primers, 34 were selected for diversity analysis, producing 222 amplified bands. Of which 216 bands depicted 97.29 per cent polymorphism with Jaccard's similarity coefficient varied from 0.19 to 0.35 . The dendrogram was constructed by Unweighted Pair Group Method Using Arithmetic Average (UPGMA), separated six Dendrobium species into two main clusters, one with four species and the other with two species. Out of 11 SSR primers, eight were selected for diversity analysis, producing 12 amplified bands. Of which eight bands depicted 66.66 per cent polymorphism with Jaccard's similarity coefficient varied from 0.37 to 0.60 . The dendrogram was constructed by UPGMA, separated six Dendrobium species into two main clusters, one with five species and the other with one species. RAPD markers were more reliable than the SSR markers. Species specific SSR markers are to be developed in future.

\section{Introduction}

Orchids are most beautiful flowering and highly evolved plants. They are the most unique plants distributed in wide range of habitats (Kull et al., 2006; Singh et al., 2007).
There are about 17,000 wild orchid species in 750 genera reported in the world (Rao 1998). Till the year 2016, 29199 accepted orchid species were reported (Govaerts et al., 2016). The orchids in India are found mostly in North Eastern region, Eastern and Western 
Ghats (Bhanwra et al., 2006). Rao (1998) has described 65 species belonging to Kodugu region of Karnataka, an important part of Western Ghats. The genus Dendrobium found to be an important genus in the Orchidaceae family with 1190 species as per the Royal Botanic Gardens, Kew. Dendrobium plants exhibit distinctive ecological diversification. They can be found in terrestrial, epiphytic, and lithophytic life forms. In addition to ornamental values, orchids like Dendrobium have therapeutic effects, viz., significant hepatoprotective activity against $\mathrm{CCl} 4$ induced hepatotoxicity (Dendrobium ovatum) (Ganpathy et al., 2013), anti-oxidant and antiglycation (Dendrobium aqueum)(Mukharjee et al., 2012), inhibitory activity on phytopathogenic fungi (Dendrobium herbaceum) (Akarsh et al.,2016), Dendrobium substances have been used in traditional medicine in many Asian countries (Bulpitt et al., 2007).

Genetic diversity studies and determination of the genetic relationship among Dendrobium species are important for the conservation and potential use of plant genetic resources to produce hybrid Dendrobium orchids. The development of molecular marker techniques for genetic variation analysis in the past decade has led to advancement analysis of orchid genetic diversity. Molecular markers have been used to study DNA sequence variation in and among orchid species (Wang et al., 2009). Related knowledge about more plant species is prerequisite for efficiently managing and exploiting Dendrobium genetic resources. In the present study, genetic diversity among six Dendrobium species from Western Ghat regions of Karnataka was established using RAPD and SSR markers.

\section{Materials and Methods}

Orchid plant samples for present study were collected mainly from Kodugu district, Western Ghats region of Karnataka. D. aqueum, D. crepidatum, D. herbaceum, $D$. jerdonianum, D. macrostachyum and $D$. Ovatum was the six species collected and established in orchidarium at College of Agriculture, Bengaluru (Table 1). Morphological characters were recorded based on descriptor for Dendrobium prescribed by Nation Research Centre on Orchids, Sikkim.

\section{Plant Genomic DNA isolation}

Tender leaves were selected for genomic DNA isolation. Leaf samples were harvested and stored at $-20^{\circ} \mathrm{C}$. Genomic DNA was isolated from leaves using modified Cetyltrimethyl ammonium bromide (CTAB) method (Khan et al., 2007). The isolated DNA was dissolved in $20 \mu \mathrm{L}$ Tris EDTA (TE) buffer. Quantity and quality of genomic DNA were determined by using NanoDrop spectrophotometer and agarose gel electrophoresis respectively.

\section{RAPD analysis}

PCR reaction for RAPD primers was carried out in $10 \mu \mathrm{L}$ reaction volume containing 50ng of genomic DNA, 1U Taq polymerase (Thermo scientific fisher), $2 \mathrm{mM}$ dNTPs, $10 \mathrm{x}$ PCR reaction buffer with $1.5 \mathrm{mM} \mathrm{MgCl}_{2}$ and 5 picomole of RAPD primer. Standardised amplification conditions consisted of Initial denaturation at $94^{\circ} \mathrm{C}$ for 5minutes, denaturation at $94^{\circ} \mathrm{C}$ for 2 minutes, annealing at $37^{\circ} \mathrm{C}$ for 1 minute 30 seconds, extension at $72^{\circ} \mathrm{C}$ for 2 minutes and final extension at $72^{\circ} \mathrm{C}$ for 8 minutes with 40 cycles. The amplified DNA products were resolved on 1.5 per cent agarose gel, visualized by Ethidium bromide staining and photographed under UV light gel documentation system.

\section{SSR analysis}

PCR reaction for SSR primers was carried out in $10 \mu \mathrm{L}$ reaction volume containing $50 \mathrm{ng}$ of 
genomic DNA, 1U Taq polymerase (Thermo scientific fisher), $2 \mathrm{mM}$ dNTPs, 10x PCR reaction buffer with $1.5 \mathrm{mM} \mathrm{MgCl}_{2}$ and 2.5 picomole of each primer (forward and reverse). Standardised amplification conditions consisted of Initial denaturation at $94^{\circ} \mathrm{C}$ for 4 minutes, denaturation at $94^{\circ} \mathrm{C}$ for 2 minutes, annealing from $48^{\circ} \mathrm{C}$ to $56^{\circ} \mathrm{C}$ (standardized for each primer pair) for 45 seconds, extension at $72^{\circ} \mathrm{C}$ for 1 minute, 30 seconds and final extension at $72^{\circ} \mathrm{C}$ for 8 minutes with 35 cycles. The amplified DNA products were resolved on 3 per cent agarose gel, visualized by Ethidium bromide staining and photographed under UV light gel documentation system.

The bands were scored based on the gel images with the presence of band scored as one ' 1 ' and absence as zero ' 0 '. Scored data were entered into binary matrix and subjected to further analysis. Similarity index was calculated using the simple clustering (SM) coefficient (Sneath and Sokal 1973). Similarity matrices were obtained using the subprogram SIMQUAL to generate pair-wise Jaccard's similarity coefficient (NTSYSpc.Version 2.0). Further, using similarity indices, the clusters were built by Unweighted Pair Group Method Using Arithmetic Average (UPGMA) procedure. A dendrogram was constructed using NTSYS-pc Version 2.0 .

\section{Results and Discussion}

The morphological study of the six species of Dendrobium was undertaken with various descriptive traits and quantitative characters. All the six Dendrobium species collected had lanceolate leaf shape with entire leaf margin (Plate 1). All the species studied are epiphytic in nature as listed (Table 2). Similarly, Dendrobium monileforme was found to have lanceolate type of leaves (Xiaohua et al., 2009).
Dendrobium aqueum and Dendrobium crepidatum were having cane clavate fleshy type of shoots, Dendrobium herbaceum and Dendrobium jerdonianum were having cane cylindrical type of shoots whereas, Dendrobium macrostachyum and Dendrobium ovatum were having cane woody type of shoots (Plate2). Similar type of results regarding leaf shape, leaf length and width were reported for Dendrobium macrostachyum. Leaves were found to have Linear-lanceolate to ovate-lanceolate shape with 4 to $10 \mathrm{~cm}$ of length and 1 to $2.4 \mathrm{~cm}$ of breadth (Reddy et al., 2002).

Dendrobium aqueum, Dendrobium crepidatum, Dendrobium macrostachyum and Dendrobium ovatum were having acute leaf apex. Dendrobium herbaceum and Dendrobium jerdonianum were found to have retuse type of leaf apex (Plate 1).

Shapes of apex of sepals and apex of petals of the species such as Dendrobium crepidatum, Dendrobium herbaceum, Dendrobium jerdonianum and Dendrobium ovatum were found to be obtuse type. Dendrobium macrostachyum was found to have acute type of apex of sepals and petals (Table 3). Four species namely, Dendrobium crepidatum, Dendrobium herbaceum, Dendrobium ovatum and Dendrobium macrostachyum had uniformly white coloured sepals and petals while, Dendrobium jerdonianum had uniformly orange coloured sepals and petals (Plate 3).

Out of 52 RAPD primers, 34 primers were amplified with high resolution for all the six Dendrobium species. The six Dendrobium species produced a total of 222 amplified bands, out of which 6 were monomorphic bands and 216 were polymorphic bands with an average of 6.35 bands per primer.

Number of bands amplified ranged from 2 
(Primer: OPE 12) to 12 (Primer: OPBA 3 and OPA 09) with mean of 6.5 bands per primer (Plate 4). Out of 34 amplified markers Primer OPE 12 showed lowest number of polymorphic bands of one (1) whereas, the OPA 09 showed highest polymorphic bands of twelve (12). The primers were 97.30 per cent polymorphic across the species, with lowest polymorphism of 50 per cent produced by OPE 12 primer and highest polymorphism of $100 \%$ produced by OPA 18, OPM 15, RD 03, RD 04, RD 11, RD 14, OPC 08, OPB 01, OPC 13, OPMA 18, OPB 04, OPA 03, OPC 01, OPE 07, OPA 15, OPA 10, OPA 02, OPA 12, OPC 11, OPA 09, OPB 12, OPA 19, OPA 08, OPA 11, OPA 04, OPA 20, OPB 08 and OPF 9 primers (Table 4).

The Jaccard's genetic similarity coefficient ranged from 0.19 to 0.35 (Table 1). The Dendrobium aqueum showed lowest similarity index (0.19) with Dendrobium herbaceum and the highest similarity index (0.35) was found between Dendrobium macrostachyum and Dendrobium ovatum. The Polymorphic Information Content (PIC) value, a reflection of allele diversity and frequency among the species, were uniformly high for all the RAPD loci tested. The PIC of studied species ranged from 0.23 for OPE 12 primer to 0.36 for OPA 10 primer with an average PIC of 0.29 (Table 5).

The dendrogram constructed separated six species into two main clusters, one with 4 species (Dendrobium aqueum, Dendrobium crepidatum, Dendrobium macrostachyum and Dendrobium ovatum) and other with two species Dendrobium herbaveum and Dendrobium jerdonianum (Fig. 1). Clusters were formed were mainly divided based on descriptive characters of the species which were measured. The four species (Dendrobium aqueum, Dendrobium crepidatum, Dendrobium macrostachyum and Dendrobium ovatum) in cluster I have acute type of leaf apex, remaining two species (Dendrobium herbaceum and Dendrobium jerdonianum) in Cluster II have retuse type of leaf apex and shortleaves. The species present in sub cluster I of first main cluster have same shoot character viz., Cane clavate (fleshy) and medium leaf length. The species present in sub cluster II of first main cluster have cane woody type of shoot nature.

Similarly, RAPD primers were used to establish phylogenetic relationship between nine Dendrobium species. Nine Dendrobium species were grouped into four main clusters using dendrogram (Zha et al., 2009). Ten RAPD primers were used by Niknejad et al. (2009) to analyse the genetic relationship between 20 Phalaenopsis species. They could group twenty Phalaenopsis species into three major groups based on similarity index between species. RAPD primers were used for cluster analysis in Vanda species by Lim et al. (1999) and in Dendrobium species by Khosravi et al. (2008).

Out of 11 SSR primer pairs, 7 primer pairs were amplified with high resolution. The six Dendrobium species produced a total of 12 amplified bands, out of which 4 were monomorphic bands and 8 were polymorphic bands with an average of 1.5 bands per primer.

Number of bands amplified ranged from one (OA 25, OA 12, OA 08 and OA) to two (DO 12, DO 03, OA 07 and OA 23) with mean of 1.5 bands per primer (Table 6). The primers were 66.66 per cent polymorphic across the species, with lowest polymorphism of 0 per cent produced by DO 03 primer and highest polymorphism of 100 per cent produced by OA 25, OA 12, OA 08, OA 07 and OA primers (Plate 5).

The Jaccard's genetic similarity coefficient ranged from 0.37 to 0.60 (Table 7). The Dendrobium crepidatum showed lowest 
similarity index (0.37) with Dendrobium herbacium and Dendrobium aqueum. Highest similarity index (0.60) was found between Dendrobium aqueum and Dendrobium herbaceum, Dendrobium macrostachyum,
Dendrobium ovatum. 0.60 similarity index was also found between Dendrobium herbaceum and Dendrobium macrostachyum, Dendrobium ovatum.

Table.1 Orchid species collected and conserved in College of Agriculture, Bengaluru

\begin{tabular}{|l|l|l|l|}
\hline Sl.No. & Species & Location & Coordinates \\
\hline $\mathbf{1}$ & D. aqueum & Ponnampet & $12^{\circ} 08^{\prime} 41.8^{\prime \prime} \mathrm{N} 75^{\circ} 56^{\prime} 17.4^{\prime \prime} \mathrm{E}$ \\
\hline $\mathbf{2}$ & D. crepidatum & Halligattu & $12^{\circ} 7^{\prime} 47.6^{\prime \prime} \mathrm{N} 75^{\circ} 55^{\prime} 18.4^{\prime \prime} \mathrm{E}$ \\
\hline $\mathbf{3}$ & D. herbaceum & B Shettigeri & $12^{\circ} 08^{\prime} 22.7^{\prime \prime} \mathrm{N} 75^{\circ} 55^{\prime} 18.7^{\prime \prime} \mathrm{E}$ \\
\hline $\mathbf{4}$ & D. jerdonianum & Kumaralli & $12^{\circ} 39^{\prime} 39.8^{\prime \prime} \mathrm{N} 75^{\circ} 42^{\prime} 17.2^{\prime \prime} \mathrm{E}$ \\
\hline $\mathbf{5}$ & D. macrostachyum & Halligattu & $12^{\circ} 07^{\prime} 47.5^{\prime \prime} \mathrm{N} 75^{\circ} 55^{\prime} 18.3^{\prime \prime} \mathrm{E}$ \\
\hline $\mathbf{6}$ & D. ovatum & Kanur & $12^{\circ} 04^{\prime} 41.9^{\prime \prime} \mathrm{N} 76^{\circ} 02^{\prime} 48.6^{\prime \prime} \mathrm{E}$ \\
\hline
\end{tabular}

Table.2 Descriptive traits (vegetative plant parts) recorded for the six Dendrobium species

\begin{tabular}{|c|l|l|l|l|l|}
\hline Sl.No. & Species name & Nature of shoot & Shape of leaf & Apex of leaf & Leaf margin \\
\hline $\mathbf{1}$ & D. aqueum & Cane clavate fleshy & Lanceolate & Acute & Entire \\
\hline $\mathbf{2}$ & D. crepidatum & Cane clavate fleshy & Lanceolate & Acute & Entire \\
\hline $\mathbf{3}$ & D. herbaceum & Cane cylindric(fleshy) & Lanceolate & Retuse & Entire \\
\hline $\mathbf{4}$ & D. jerdonianum & Cane cylindric(fleshy) & Lanceolate & Retuse & Entire \\
\hline $\mathbf{5}$ & D. macrostachyum & Cane woody & Lanceolate & Acute & Entire \\
\hline $\mathbf{6}$ & D. ovatum & Cane woody & Lanceolate & Acute & Entire \\
\hline
\end{tabular}

Table.3 Sepal and petal morphological characters of flowers of Dendrobium species

\begin{tabular}{|l|l|l|l|l|l|l|}
\hline Species & $\begin{array}{l}\text { Apex of } \\
\text { sepal }\end{array}$ & $\begin{array}{l}\text { Shape of } \\
\text { sepal }\end{array}$ & $\begin{array}{l}\text { Sepal } \\
\text { dominan } \\
\text { t colour }\end{array}$ & $\begin{array}{l}\text { Apex of } \\
\text { petal }\end{array}$ & $\begin{array}{l}\text { Shape of } \\
\text { petal }\end{array}$ & $\begin{array}{l}\text { Petal } \\
\text { dominant } \\
\text { colour }\end{array}$ \\
\hline D. crepidatum & Obtuse & Oblong & White & Obtuse & Oblong & White \\
\hline D. herbaceum & Obtuse & Linear & White & Obtuse & Linear & White \\
\hline D. jerdonianum & Obtuse & Linear & Orange & Obtuse & Linear & Orange \\
\hline D. macrostachyum & Acute & Oblong & White & Acute & Oblong & White \\
\hline D. ovatum & Obtuse & Oblong & White & Obtuse & Oblong & White \\
\hline
\end{tabular}


Table.4 Description of the RAPD products obtained from six Dendrobium species

\begin{tabular}{|c|c|c|c|c|c|}
\hline Sl. No & Primer name & No. of bands & $\begin{array}{l}\text { No. of polymorphic } \\
\text { bands }\end{array}$ & $\begin{array}{c}\text { Polymorphism } \\
(\%)\end{array}$ & PIC \\
\hline 1. & OPA 05 & 7 & 6 & 85.71 & 0.28 \\
\hline 2. & OPA 18 & 7 & 7 & 100 & 0.29 \\
\hline 3. & OPBA 03 & 12 & 10 & 83.33 & 0.27 \\
\hline 4. & OPE 12 & 2 & 1 & 50 & 0.23 \\
\hline 5. & OPM 15 & 9 & 9 & 100 & 0.30 \\
\hline 6. & RD-03 & 10 & 10 & 100 & 0.30 \\
\hline 7. & RD-04 & 7 & 7 & 100 & 0.30 \\
\hline 8. & RD-05 & 11 & 9 & 81.81 & 0.26 \\
\hline 9. & RD-11 & 7 & 7 & 100 & 0.32 \\
\hline 10. & RD-14 & 6 & 6 & 100 & 0.35 \\
\hline 11. & OPC 08 & 6 & 6 & 100 & 0.31 \\
\hline 12. & OPB 01 & 3 & 3 & 100 & 0.32 \\
\hline 13. & OPC 13 & 10 & 10 & 100 & 0.32 \\
\hline 14. & OPAM 18 & 6 & 6 & 100 & 0.31 \\
\hline 15. & OPB 09 & 6 & 6 & 100 & 0.30 \\
\hline 16. & OPA 03 & 9 & 9 & 100 & 0.30 \\
\hline 17. & OPC 02 & 4 & 3 & 75 & 0.24 \\
\hline 18. & OPC 01 & 3 & 3 & 100 & 0.27 \\
\hline 19. & OPE 7 & 6 & 6 & 100 & 0.30 \\
\hline 20. & OPA 15 & 4 & 4 & 100 & 0.27 \\
\hline 21. & OPA 10 & 3 & 3 & 100 & 0.36 \\
\hline 22. & OPA 02 & 6 & 6 & 100 & 0.32 \\
\hline 23. & OPA 12 & 8 & 8 & 100 & 0.28 \\
\hline 24. & OPC 11 & 5 & 5 & 100 & 0.30 \\
\hline 25. & OPA 09 & 12 & 12 & 100 & 0.30 \\
\hline 26. & OPB 12 & 6 & 6 & 100 & 0.29 \\
\hline 27. & OPA 07 & 6 & 5 & 83.33 & 0.21 \\
\hline 28. & OPA 19 & 5 & 5 & 100 & 0.28 \\
\hline 29. & OPA 08 & 4 & 4 & 100 & 0.35 \\
\hline 30. & OPA 11 & 5 & 5 & 100 & 0.34 \\
\hline 31. & OPA 04 & 10 & 10 & 100 & 0.31 \\
\hline 32. & OPA 20 & 6 & 6 & 100 & 0.29 \\
\hline 33. & OPB 08 & 4 & 4 & 100 & 0.35 \\
\hline \multirow[t]{2}{*}{34.} & OPF 9 & 7 & 7 & 100 & 0.30 \\
\hline & Mean & 6.53 & 6.35 & 95.85 & 0.29 \\
\hline
\end{tabular}


Table.5 Similarity indices of six Dendrobium species using RAPD markers

\begin{tabular}{|l|c|c|c|c|c|c|}
\hline & $\begin{array}{l}\text { Dendrobium } \\
\text { aqueum }\end{array}$ & $\begin{array}{l}\text { Dendrobium } \\
\text { crepidatum }\end{array}$ & $\begin{array}{l}\text { Dendrobium } \\
\text { herbaceum }\end{array}$ & $\begin{array}{l}\text { Dendrobium } \\
\text { jerdonianum }\end{array}$ & $\begin{array}{l}\text { Dendrobium } \\
\text { macrostachyum }\end{array}$ & $\begin{array}{l}\text { Dendrobium } \\
\text { ovatum }\end{array}$ \\
\hline $\begin{array}{l}\text { Dendrobium } \\
\text { aqueum }\end{array}$ & 1.00 & & & & & \\
\hline $\begin{array}{l}\text { Dendrobium } \\
\text { crepidatum }\end{array}$ & 0.32 & 1.00 & & & & \\
\hline $\begin{array}{l}\text { Dendrobium } \\
\text { herbaceum }\end{array}$ & 0.19 & 0.22 & 1.00 & & & \\
\hline $\begin{array}{l}\text { Dendrobium } \\
\text { jerdonianum }\end{array}$ & 0.29 & 0.25 & 0.34 & 1.00 & & \\
\hline $\begin{array}{l}\text { Dendrobium } \\
\text { macrostachyum }\end{array}$ & 0.27 & 0.24 & 0.22 & 0.28 & 1.00 & \\
\hline $\begin{array}{l}\text { Dendrobium } \\
\text { ovatum }\end{array}$ & 0.26 & 0.26 & 0.24 & 0.24 & 0.35 & \\
\hline
\end{tabular}

Table.6 Description of the SSR products obtained from six Dendrobium species

\begin{tabular}{|l|l|c|c|c|c|}
\hline $\begin{array}{c}\text { Sl. } \\
\text { No. }\end{array}$ & $\begin{array}{c}\text { Primer } \\
\text { name }\end{array}$ & $\begin{array}{c}\text { No. of } \\
\text { bands }\end{array}$ & $\begin{array}{c}\text { No. of polymorphic } \\
\text { bands }\end{array}$ & Polymorphism (\%) & PIC \\
\hline $\mathbf{1}$ & DO 12 & 2 & 1 & 50 & 0.11 \\
\hline $\mathbf{2}$ & OA 25 & 1 & 1 & 100 & 0.34 \\
\hline $\mathbf{3}$ & OA 12 & 1 & 1 & 100 & 0.34 \\
\hline $\mathbf{4}$ & DO 03 & 2 & 0 & 0 & 0.00 \\
\hline $\mathbf{5}$ & OA 08 & 1 & 1 & 100 & 0.24 \\
\hline $\mathbf{6}$ & OA 07 & 2 & 2 & 100 & 0.24 \\
\hline $\mathbf{7}$ & OA & 1 & 1 & 100 & 0.24 \\
\hline $\mathbf{8}$ & OA 23 & 2 & 1 & 50 & 0.17 \\
\hline & MEAN & $\mathbf{1 . 5}$ & $\mathbf{1}$ & $\mathbf{7 5}$ & $\mathbf{0 . 2 1}$ \\
\hline
\end{tabular}


Table.7 Similarity indices of six Dendrobium species using SSR markers

\begin{tabular}{|l|c|c|c|c|c|c|}
\hline & $\begin{array}{l}\text { Dendrobium } \\
\text { aqueum }\end{array}$ & $\begin{array}{l}\text { Dendrobium } \\
\text { crepidatum }\end{array}$ & $\begin{array}{l}\text { Dendrobium } \\
\text { herbaceum }\end{array}$ & $\begin{array}{l}\text { Dendrobium } \\
\text { jerdonianum }\end{array}$ & $\begin{array}{l}\text { Dendrobium } \\
\text { macrostachyum }\end{array}$ & $\begin{array}{l}\text { Dendrobium } \\
\text { ovatum }\end{array}$ \\
\hline $\begin{array}{l}\text { Dendrobium } \\
\text { aqueum }\end{array}$ & 1.00 & & & & & \\
\hline $\begin{array}{l}\text { Dendrobium } \\
\text { crepidatum }\end{array}$ & 0.37 & 1.00 & & & & \\
\hline $\begin{array}{l}\text { Dendrobium } \\
\text { herbaceum }\end{array}$ & 0.60 & 0.37 & 1.00 & & & \\
\hline $\begin{array}{l}\text { Dendrobium } \\
\text { jerdonianum }\end{array}$ & 0.43 & 0.44 & 0.42 & 1.00 & & \\
\hline $\begin{array}{l}\text { Dendrobium } \\
\text { macrostachyum }\end{array}$ & 0.60 & 0.57 & 0.60 & 0.42 & 1.00 & \\
\hline $\begin{array}{l}\text { Dendrobium } \\
\text { ovatum }\end{array}$ & 0.60 & 0.57 & 0.60 & 0.42 & 0.60 & 1.00 \\
\hline
\end{tabular}

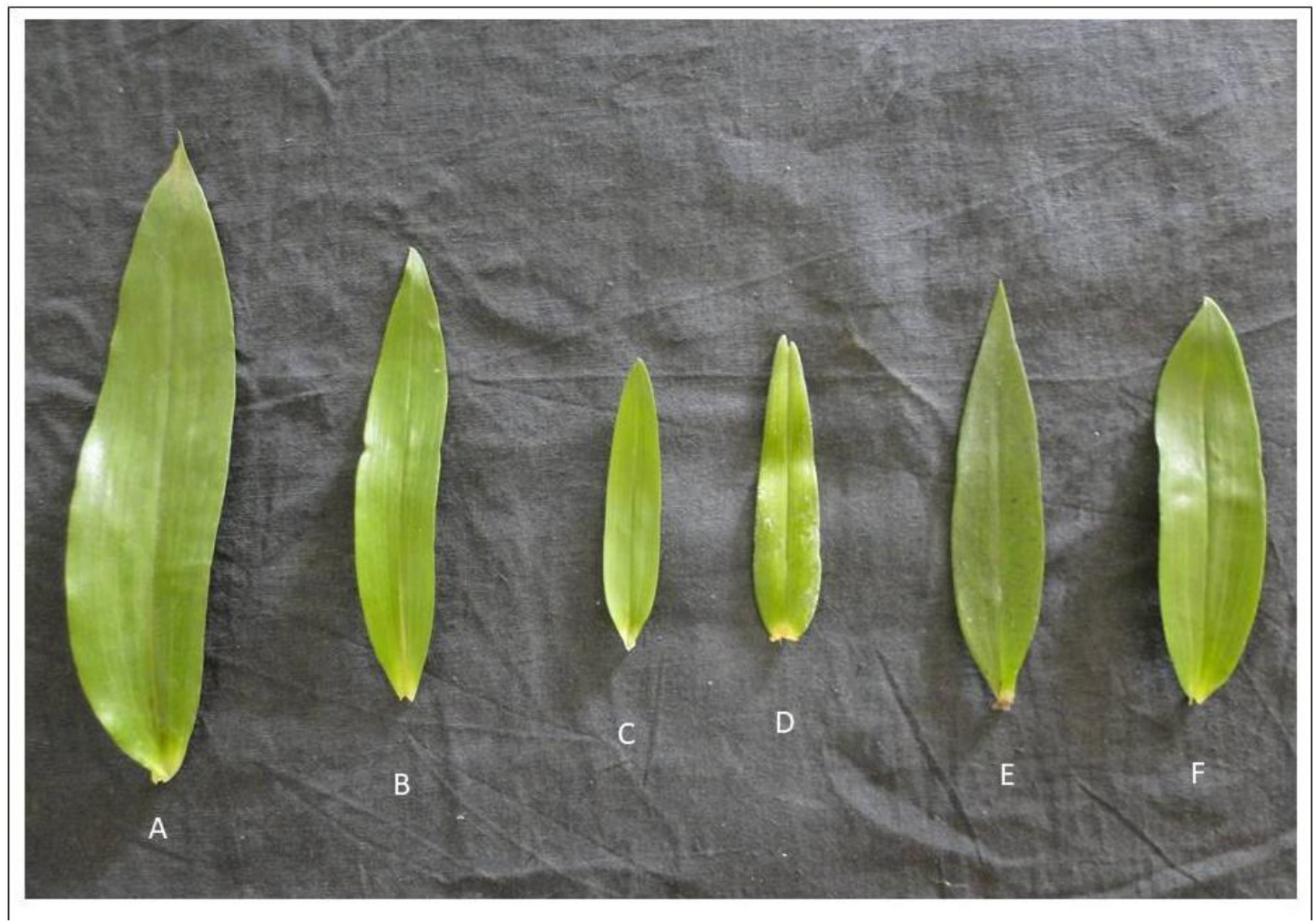

Plate.1 Shape of leaf apex of six Dendrobium species

A: Dendrobium aqueum; B: Dendrobium macrostachyum; C: Dendrobium ovatum; D: Dendrobium herbceum; E: Dendrobium jerdonianum; F: Dendrobium crepidatum. 


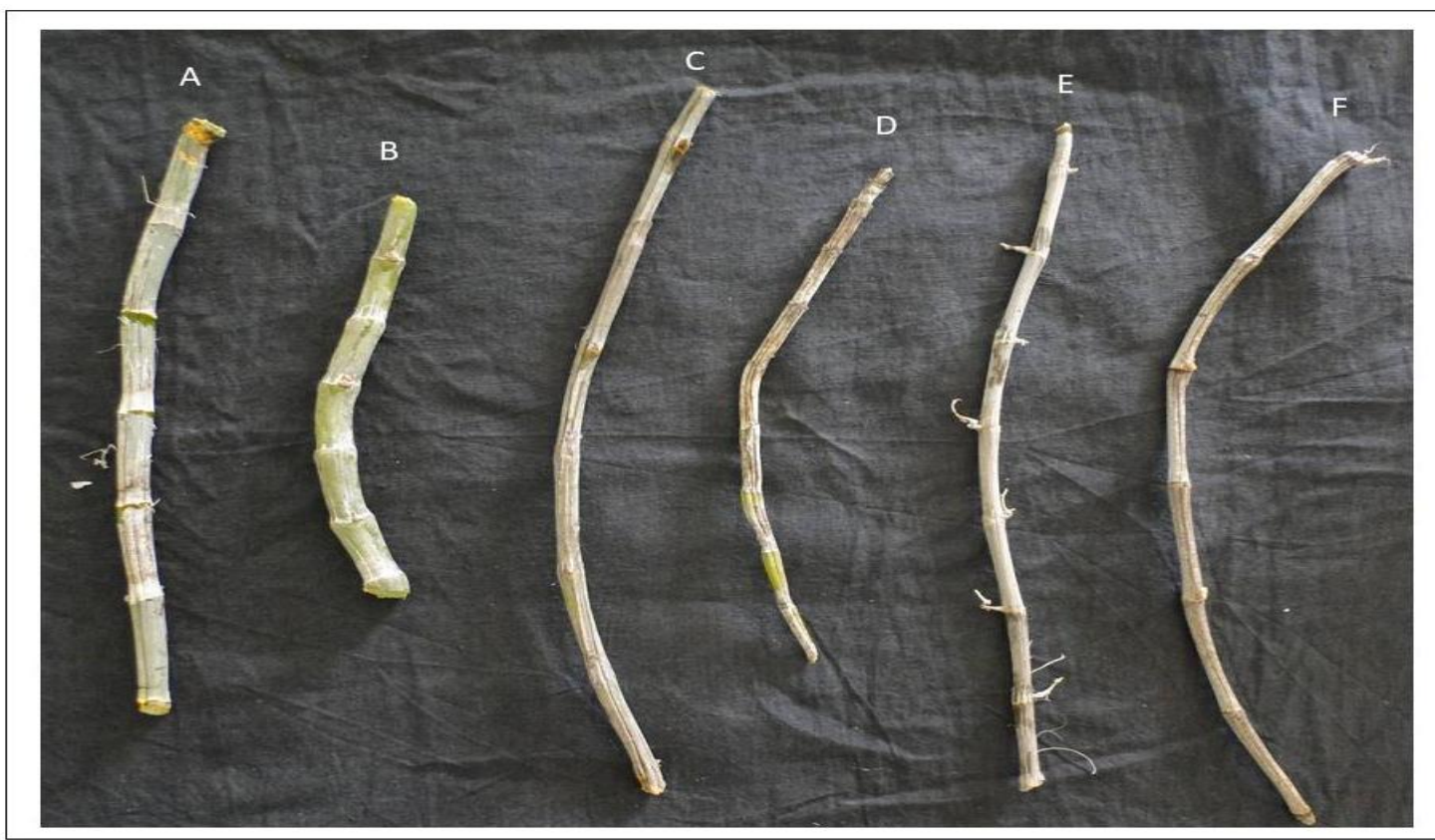

Plate.2 Nature of shoots of six Dendrobium species

A: Dendrobium aqueum; B: Dendrobium crepidatum; C: Dendrobium herbaceum; D: Dendrobium jerdonianum; E: Dendrobium macrostachyum; F: Dendrobium ovatum.
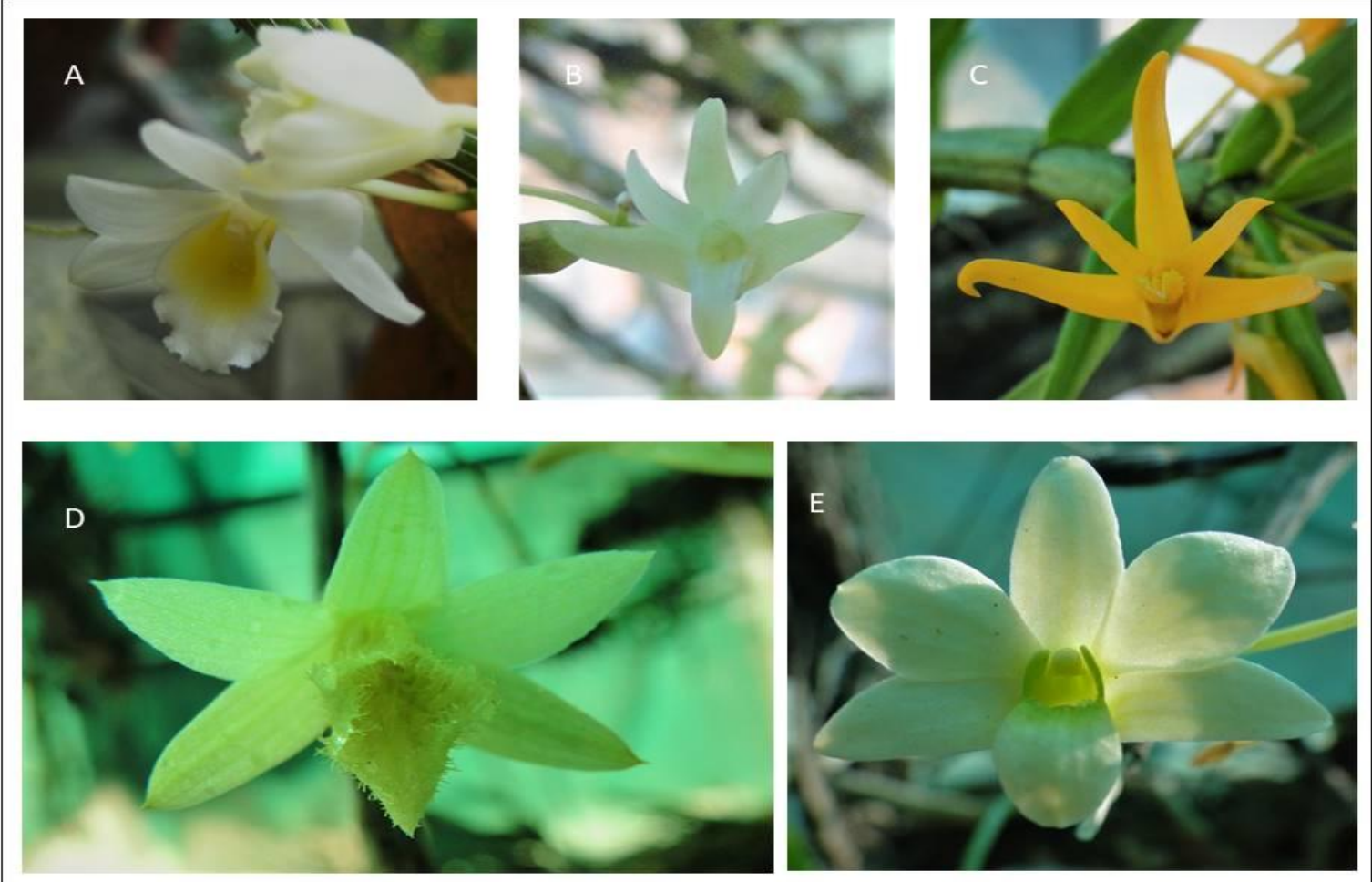

Plate.3 Flower morphology of Dendrobium species

A: Dendrobium crepidatum; B: Dendrobium herbaceum; C: Dendrobium jerdonianum; D: Dendrobium macrostachyum; E: Dendrobium ovatum 


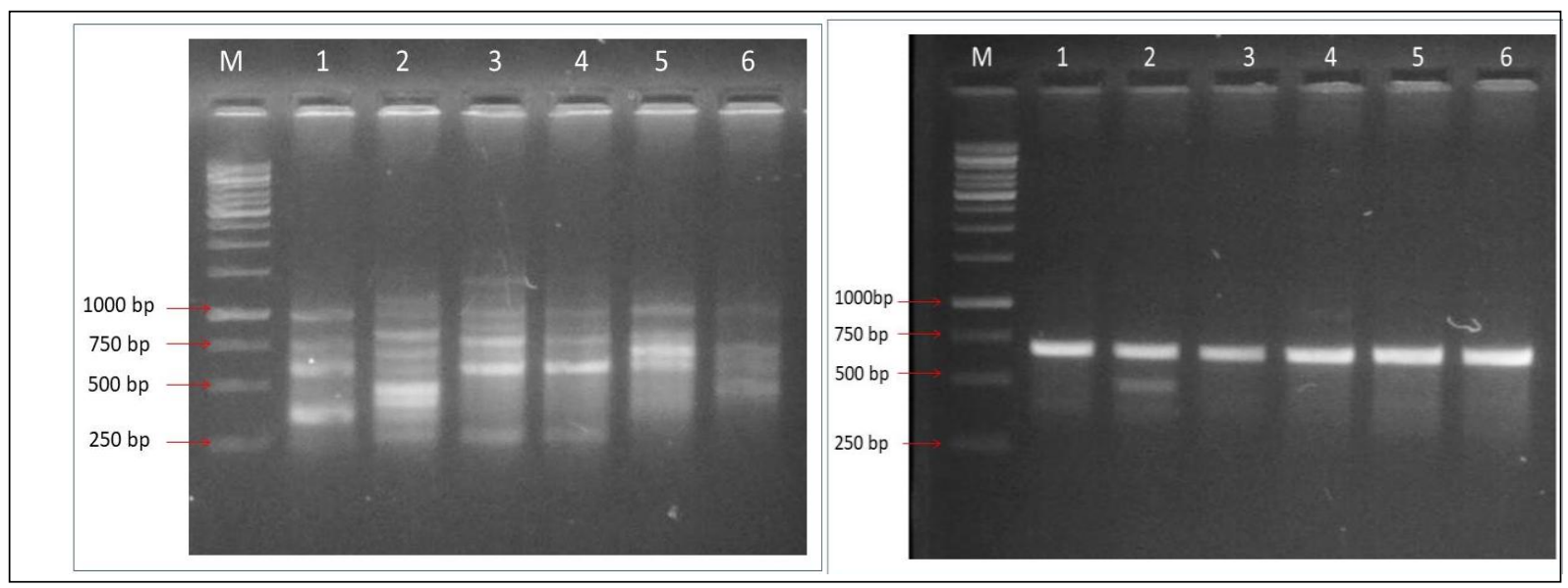

Plate.4 RAPD banding pattern of six Dendrobium species obtained with OPBA 3 and OPE 12. M: ladder (1kb); Lane 1: D. Aqueum; Lane 2: D. Crepidatum; Lane 3: D. herbaceum; Lane 4: D. Jerdonianum; Lane 5: D. Macrostachyum; Lane 6: D. ovatum

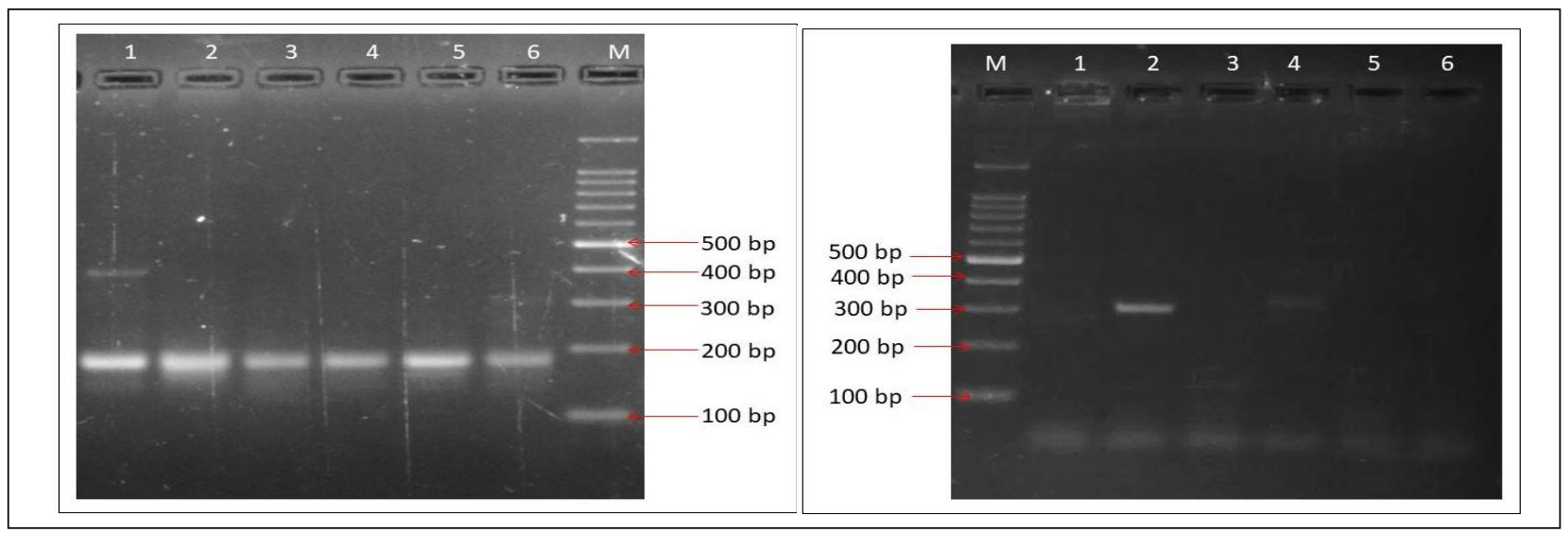

Plate.5 SSR banding pattern of six Dendrobium species obtained with DO 12 and OA 25. M:Ladder(1kb); Lane 1: D. Aqueum; Lane 2: D. Crepidatum; Lane 3: D .herbaceum; Lane 4: $D$. Jerdonianum; Lane 5: D. Macrostachyum; Lane 6: D. ovatum

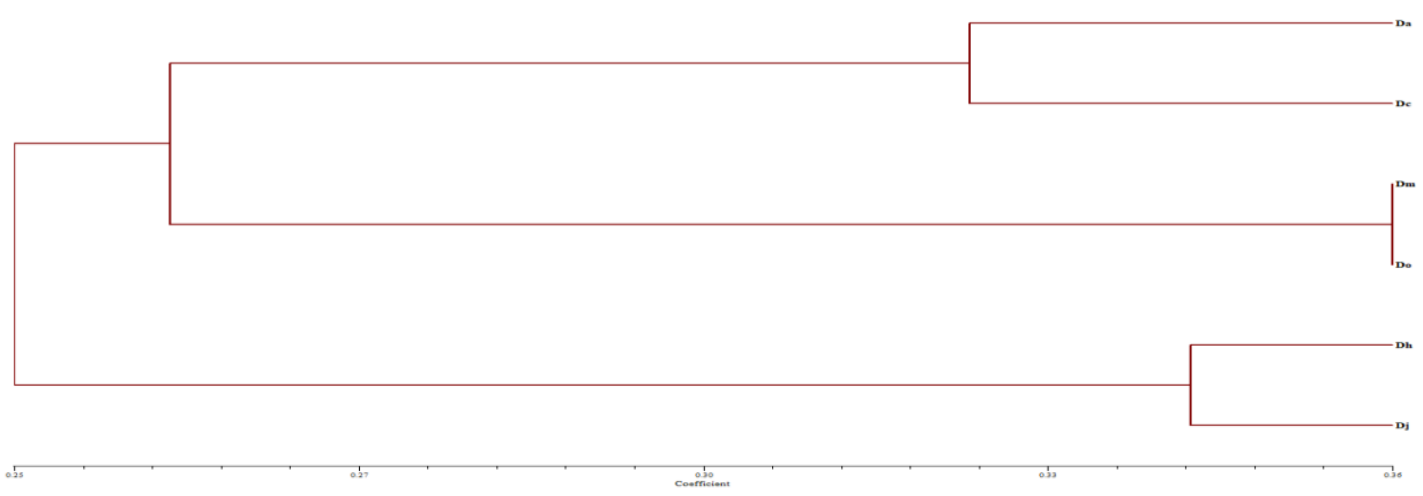

Fig.1 UPGMA dendrogram representing relationship among six Dendrobium species using RAPD markers. Da: Dendrobium aqueum; Dc: Dendrobium crepidatum; Dh: Dendrobium herbaceum; Dj: Dendrobium jerdonianum and Dm: Dendrobium macrostachyum; Do:

Dendrobium ovatum 


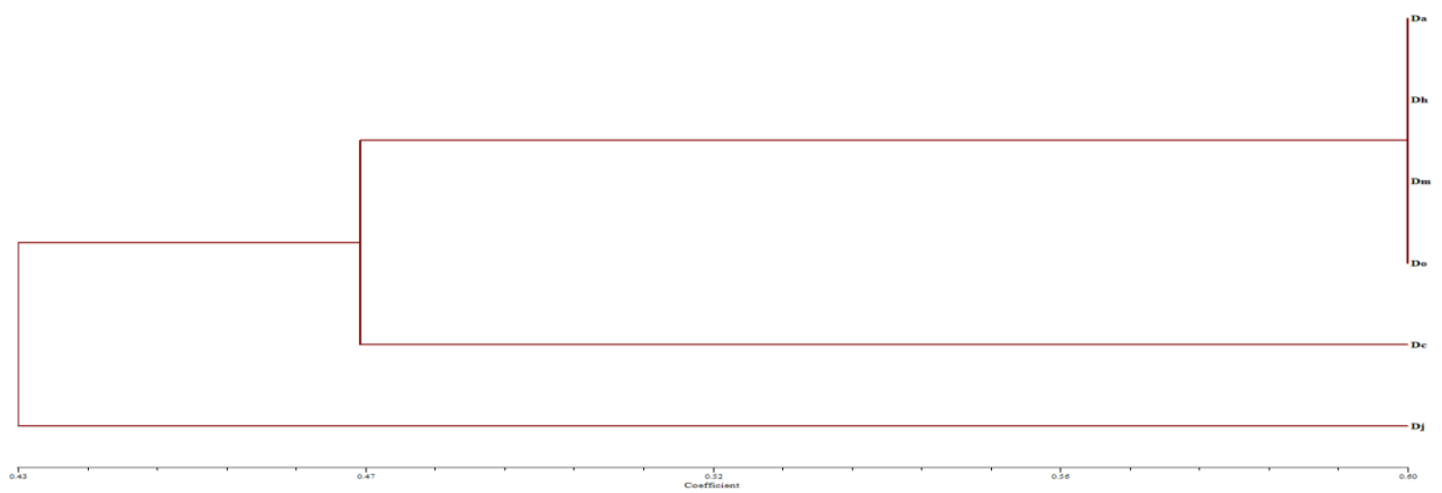

Fig.2 UPGMA dendrogram representing relationship among six Dendrobium species using SSR markers. Da: Dendrobium aqueum; Dc: Dendrobium crepidatum; Dh: Dendrobium herbaceum; Dj: Dendrobium jerdonianum and Dm: Dendrobium macrostachyum; Do: Dendrobium ovatum

The dendrogram constructed separated the six species into two main clusters, one with five species (Dendrobium aqueum, Dendrobium crepidatum, Dendrobium macrostachyum, Dendrobium herbaceum and Dendrobium ovatum) and other with one species (Dendrobium jerdonianum) (Fig. 2).

Clusters were formed based on descriptive and quantitative characters. The five species in cluster I have whitish coloured flowers; Dendrobium jerdonianum in Cluster II has orange coloured flowers. Similarly, SSR markers were used to determine the genetic variability among 12 Dendrobium Species and species specific SSR markers were identified by Liu et al. (2014). The individuals of Dendrobium officinale collected from different places were differentiated by using 13 SSR markers (Lu et al., 2012).

The phylogenetic relationship among the species obtained using RAPD markers was found to be more relevant, because the species which were grouped into same main and sub-clusters were found to have similar morphologically descriptive characters. The phylogenetic relationship among the species obtained using SSR markers was able to differentiate the species based on the flower colour morphology.

\section{References}

Akarsh, S., Prashith, T. R., Ranjitha, M. C., Vidya, P. and Firdos, G. F., 2016, Inhibitory activity of some plants against Colletotrichum capsici and Fusarium oxysporum f. sp. zingiberi. J. Med. Plants Stud., 4: 165-168.

Bhanwra, R. K., Vij, S. P., Chandel, V., Dutt, R. and Dutt, S., 2006, Development of polonium in two epidendroid orchids. Curr. Sci., 1384-1388.

Bulpitt, C. J., Li, Y., Bulpitt, P. F. and Wang, J., 2007, The use of orchids in Chinese medicine. $J$. the Royal Society of Med., 100(12): 558-563.

Chattopadhyay, P., Banerjee, N. and Chaudhary, B., 2012, Genetic characterization of selected medicinal Dendrobium (Orchidaceae) species using molecular markers. Res $J$ Biol., 2(4): 117-125.

Ganapaty, S., Ramaiah, M., Yasaswini, K., Nuthakki, V.K. and Harikrishna Reddy, D., 2013. Quantitative phytochemical estimation and evaluation of hepatoprotective activity of methanolic extract of Dendrobium ovatum (L.) Kraenzl whole plant against $\mathrm{CCl} 4$ induced hepatotoxicity. J Pharmacogn. Phytochem., 2(3): 113-118.

Govaerts, R., Bernet, P., Kratochvil, K., 
Gerlach, G., Carr, G., Alrich, P. and Tigges, H. 2016, World Checklist of Orchidaceae. Facilitated by the Royal Botanic Gardens, Kew.

Khan, S., Qureshi, M. I., Alam, T. and Abdin, M. Z., 2007, Protocol for isolation of genomic DNA from dry and fresh roots of medicinal plants suitable for RAPD and restriction digestion. Afr. J. Biotechnol.,6(3):175-178.

Khosravi, A. R., Kadir, M. A., Kadzemin, S. B., Zaman, F. Q. and De Silva, A. E., 2009, RAPD analysis of colchicine induced variation of the Dendrobium Serdang beauty. Afr. J. Biotechnol., $8(8)$.

Kull, T. and Hutchings, M. J., 2006, A comparative analysis of decline in the distribution ranges of orchid species in Estonia and the United Kingdom. Biol. Cons., 129(1):31-39.

Lim, S. H., Teng, P. C. P., Lee, Y. H. and Goh, C. J., 1999, RAPD analysis of some species in the genus Vanda (Orchidaceae). Ann. Bot., 83(2):193196.

Liu, Y. T., Chen, R. K., Lin, S. J., Chen, Y. C., Chin, S. W., Chen, F. C. and Lee, C. Y., 2014, Analysis of sequence diversity through internal transcribed spacers and simple sequence repeats to identify Dendrobium species.Genet. Mol. Res., 13(2): 2709-2717.

Lu, J. J., Suo, N. N., Hu, X., Wang, S., Liu, J. J. and Wang, H. Z., 2012, Development and characterization of 110 novel ESTSSR markers for Dendrobium officinale (Orchidaceae). Am. J. Bot., 99(10):415420.

Mukherjee, S., Phatak, D., Parikh, J., Jagtap, S., Shaikh, S. and Tupe, R. 2012, Antiglycation and antioxidant activity of a rare medicinal orchid Dendrobium aqueum Lindl.Med. Chem. Drug. Discov., 2(2): 17-29.

Niknejad, A., Kadir, M. A., Kadzimin, S. B., Abdullah, N. A. P. and Sorkheh, K., 2009, Molecular characterization and phylogenetic relationships among and within species of Phalaenopsis (Epidendroideae: Orchidaceae) based on RAPD analysis. Afr. J. Biotechnol., 8 (20): 5225-5240.

Rao, T. A., 1998, Conservation of Wild Orchids of Kodagu in the Western Ghats. Information systems division, National Agricultural Library: 242.

Reddy, K. N., Reddy, C. S. and Jadhav, S. N., 2002, Dendrobium macrostachyum Lindl. (Orchidaceae): A new Record for Andhra Pradesh, India. Bot. J. Linn. Soc., 6(2): 35-38

Singh, A.K.R. Mer. and C. Tiwari., 2007, Harnessing the economic potential of Orchids in Uttaranchal. ENVIS Bulletin on Himalayan Ecology.14 (2).

Sneath, P. H. and Sokal, R. R., 1973, Numerical taxonomy. The principles and practice of numerical classification.

Wang, H. Z., Feng, S. G., Lu, J. J., Shi, N. N. and Liu, J. J., 2009, Phylogenetic study and molecular identification of 31 Dendrobium species using inter-simple sequence repeat (ISSR) markers. Sci. Hortic., 122(3):440-447.

Xiaohua, J., Singchi, C. and Yibo, L., 2009, Taxonomic revision of Dendrobium moniliforme complex (Orchidaceae). Scientia horticulturae., 120(1):143-145.

Zha, X., Luo, J., Wang, J., Wei, Z. and Jiang, S., 2009, Genetic characterization of the nine medicinal Dendrobium species using RAPD. Afr. J. Biotechnol., 8:(10). 


\section{How to cite this article:}

Basavaraj, B., N. Nagesha and Jadeyegowda, M. 2020. Molecular Characterization of Dendrobium Orchid Species from Western Ghat Region of Karnataka using RAPD and SSR Markers. Int.J.Curr.Microbiol.App.Sci. 9(01): 2157-2169.

doi: https://doi.org/10.20546/ijcmas.2020.901.246 